\title{
Antibacterial activity of Zingiber Officinale Roscoe extract as a potential root canal irrigation solution against Enterococcus faecalis
}

\author{
Rodiyah Azhar*, Elin Julianti**, Setiawan Natasasmita***, Hendra Dian Adhita \\ Dharsono***
}

*Endodontics Clinic Bratanata Army Hospital Jambi, Indonesia

**Department of Pharmacochemistry School of Pharmacy, Bandung Institute of Technology, Indonesia

***Department of Conservative Dentistry Faculty of Dentistry, Universitas Padjadjaran, Indonesia

\section{ABSTRACT}

Introduction: The aim of this study was to determine and formulate antibacterial activity of Zingiber Officinale Roscoe (Z. officinale) extract against Enterococcus faecalis (E. faecalis) as a potential irrigating solution which are easily available and cost-effective. Methods: Extract of Z. officinale Roscoe was yielded through soxhlet technique. Samples devided into two groups, i.e, the extract of $Z$. officinale Roscoe and clorhexidine $2 \%$ as control. The antimicrobial activity was observed using diffuse agar method. Minimum inhibitory concentration (MIC) was determined by serial microdilution method and minimum bactericidal concentration $(M B C)$ was determined by cultured samples in blood agar. Data were analyzed using Anova and Kruskal-Wallis test. Results: Extract of Zingiber officinale Roscoe has antimicrobial activity againts E. faecalis with the MBC of $15.625 \mathrm{mg} / \mathrm{mL}$. $(\mathrm{p}<0,05)$. Conclusion: Extract of Zingiber officinale Roscoe have shown antibacterial activity againts $E$. faecalis and can be further developed as a potential root canal irrigation solution.

Keywords: Antibacterial activity, Enterococcus faecalis, extract of Zingiber officinale Roscoe, root canal irrigating solution.

p-ISSN: 1979-020; e-ISSN: 2549-6212; Available from: http://jurnal.unpad.ac.id/pjd/article/view/18328

DOI: http://dx.doi.org/10.24198/pjd.vol30no2.18328

Submission: Aug 15, 2017; Accepted: May 29, 2018; Published online: July 31, 2018

\section{INTRODUCTION}

Bacteria are among the main causes of periapical infections.. It has been reported that success rate of root canal treatment was higher when teeth were free of bacteria after chemomechanical instrumentation ${ }^{1}$. While instruments are important in removal of the infected dentine from the main root canal, irrigants play an indispensable role in areas inaccessible to instruments, such as lateral and accessory canals as well as fins and webs throughout the canal ${ }^{2}$. Irrigation of the root

Corresponding author: Hendra Dian Adhita Dharsono, Department of Conservative Dentistry, Faculty of Dentistry, Unpad Sekeloa Selatan I, Bandung 40132, Indonesia. Phone: +62 815-6223-343. E-mail: adhita@fkg.unpad.ac.id 
canals with antibacterial solutions is a mandatory step to reduce or eliminate microorganisms or their byproducts from the root canal system ${ }^{3}$. Considering the ineffective, potential side effects and safety concerns of synthetic drugs, the herbal alternatives may prove to be advantageous for endotonic usage ${ }^{4}$. Natural products have been used in dental and medical practice for thousands of years and have become even more popular nowadays because of their high antimicrobial activity, biocompatibility, antioxidant and antiinflammatory properties ${ }^{4}$.

Ginger (Zingiber officinale), a member of the Zingiberaceae family, is widely used spice in the daily diet in many Asian countries ${ }^{5}$. It is a rhizomatous plant grown throughout Southeastern Asia, China and in parts of Japan, Austria, Latin America, Jamaica and Africa. It has been used as a spice and medicine in India and China since ancient times. It was known in Germany and France in the ninth century and in England in 10th century for its medicinal properties ${ }^{6}$.

Over three quarters of the world population still rely on plants and plant extracts for health care $^{6}$. Ginger compounds are active against specific type of diarrhea which is leading to cause death in infant in developing countries. Moreover, it has been found that ginger is effective in treating nausea caused by sea sickness, morning sickness and chemotherapy, though it was found superior over a place for post operative nausea ${ }^{7}$. In addition, it has been reported that the main ingredients of ginger like volatile oil, gingerol, shogaol and diarylheptanoids work as antibacteria, antioxidant, anti-inflammatory, anti-lipid, antidiabetic, analgesic, antipyretic, and anti-tumor ${ }^{5-15}$.

Ethanol and $n$-hexane fractions of ginger exhibited antibacterial activities against anaerobic bacteria associated with periodontitis of the human oral cavity ${ }^{16}$. Extract of its leaves and roots could be used alongside with conventional antibiotics to fight against infections ${ }^{17}$. Moreover, it was found that the extract was effective against Candida albicans ${ }^{18}$. Furthermore, ginger extract was found to be active Enterococcus faecalis compared with sodium hypochlorite ${ }^{19}$. In this study the possible antibacterial activity of $Z$. officinale extract is to be compared with $2 \%$ chlorohexidine as the gold standard for antibacterial activity against a wide range of Gram positive and Gram negative organisms as well as yeast, facultative anaerobes and aerobes ${ }^{20}$. In addition to its ability to be adsorbed by dental tissue and mucous membrane with prolonged gradual release at therapeutic level (substantivity) ${ }^{21}$.

The aim of this study was to determine and formulate antibacterial activity extract of Zingiber officinale Roscoe to $E$. faecalis as potential root canal irrigating solution which easily available, cost effective, increased shelf life, low toxicity compare to the gold standard of irrigation solution.

\section{METHODS}

Preparation of the irrigating solution Zingiber officinale Roscoe, Zingiber officinale Roscoe was originally from Ciwidei, Baandung determinated by Bandungense Herbarium Laboratory, Bandung Institute of Technology. Five hundreds grams of sliced fresh rhizomes were extracted with $95 \%$ ethanol for 72 hour at room temperature. The extract was then filtered through Whatman No. 1 filter paper, concentrated with a rotary evaporator (Büchi Company, Flawil, Switzerland) and kept in a desiccator overnight. The residue was then dissolved in aquadest in order to bring to a concentration of $1000 \mathrm{mg} / \mathrm{mL}$.

Evaluation of the antibacterial activity using agar well diffusion test, Lawn culture of $E$. faecalis was prepared on a TSA plate. Wells of $6,5 \mathrm{~mm}$ depth and $6 \mathrm{~mm}$ diameters were prepared, which were filled with $40 \mu \mathrm{L}$ of $1000 \mathrm{mg} / \mathrm{mL}$ of the extracts. Two percents of chlorhexidine was used as the positive control. Plates were incubated at $37^{\circ} \mathrm{C}$ for 24 hours. Interpretation of diffusion results was carried out by noting the presence or absence of zone of inhibition around the wells.

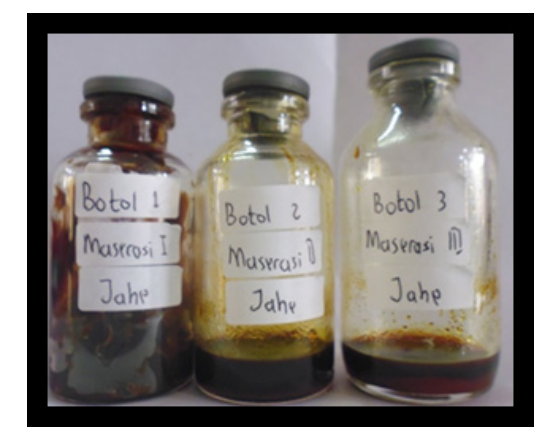

Picture 1. Extract of Zingiber Officinale Roscoe 


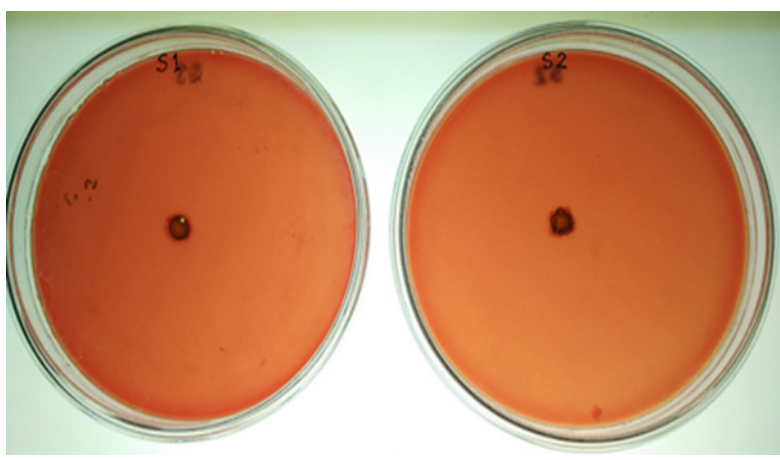

A

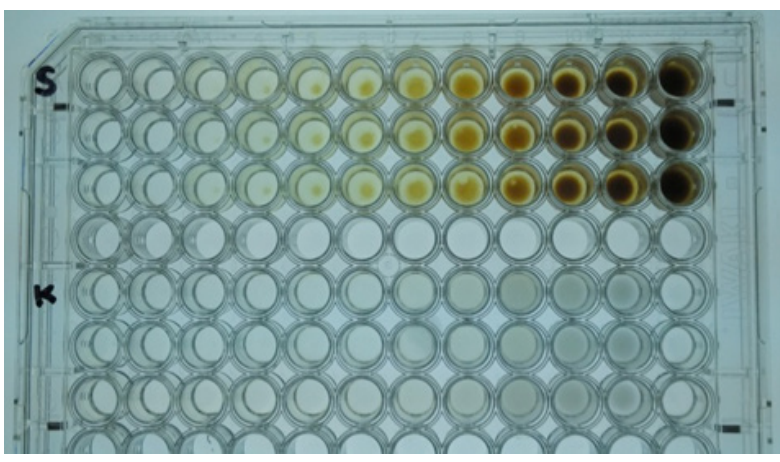

B
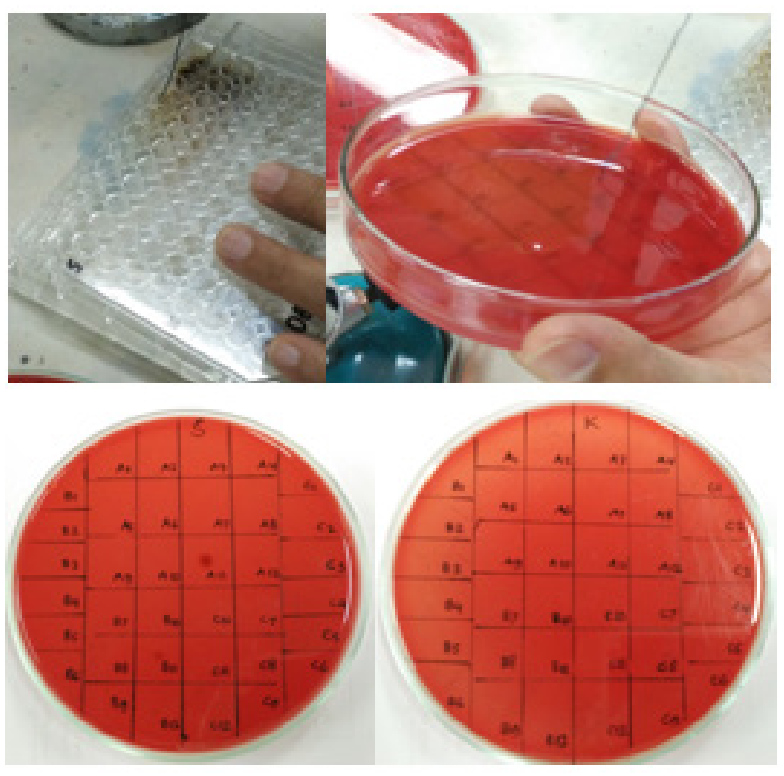

C

Picture 2. A. E faecalis was cultured on TSA plate with the sample disc in the center, zone of inhibition was then observed for their antibacterial activities; B. Microplate used for determining the minimum inhibitory concentration (MIC) of Zingiber officinale Roscoe extract and clorhexidine against $E$ faecalis; $C$. Procedure of determining the minimum bactericidal concentration (MBC) of Zingiber officinale Roscoe extract and $2 \%$ clorhexidine.
Minimum Inhibitory Concentration (MIC) and Minimum Bactericidal Concentration (MBC), Extract of Zingiber officinale Roscoe were dissolved in aquadest and diluted with culture broth to a concentration of $500 \mathrm{mg} / \mathrm{mL}$. Further $1: 2$ serial dilutions were performed by addition of culture broth to reach concentrations ranging from 500 to $0.977 \mathrm{mg} / \mathrm{mL} ; 100 \mu \mathrm{L}$ of each dilution were distributed in 96-well plates, as well as a sterility control and a growth control (pure culture broth). Each test and growth control well was inoculated with $10 \mu \mathrm{l}$ of $E$. faecalis suspension in TSB with 0.5 McFarland solution. All experiments were performed in triplicate and the microdilution trays were incubated at $37^{\circ} \mathrm{C}$ for 24 hour. After the incubation, the MIC values were determined by visual inspection of the wells. In each series of wells, the last wells with clear supernatant was considered to be without any growth and taken as MIC value. Turbidity in the MIC tube indicated growth of bacterial strain implying that $E$. faecalis was resistant to ethanolic extract of Zingiber officinale Roscoe.

MBC (Minimum Barctericidal concentration), was determined by sub culturing the contents of selective wells into blood agar. Each of the selected sample in well in the microplate was inoculated in to blood agar containing petri plate by $0.1 \mathrm{~mL}$ sterile tips in drop method. The plates were incubated at $37^{\circ} \mathrm{C}$ for 24 hours.

Results were expressed as mean value \pm standard error of the mean (SEM) of growth inhibition zones diameters obtained by extracts of Zingiber officinale Roscoe. Statistical differences between extract of Zingiber officinale Roscoe and clorhexidine were detected by Kruskal Wallis analysis and analysis of variance (ANOVA) to compare diameters of inhibition ethanolic extract of Zingiber officinale Roscoe and clorhexidine. $\mathrm{P}$ values lower than $0.05(p<0.05)$ were considered significant.

\section{RESULT}

According to antibacterial activity tested by agar diffusion method in this study, $100 \%$ extract of Zingiber officinale Roscoe had a mean zones of inhibition growth for E. Faecalis of $31,40 \mathrm{~mm}$ (p $<0.01$ ) while $2 \%$ clorhexidine was $19,24 \mathrm{~mm}$. This preliminary screening test showed that $E$. faecalis 


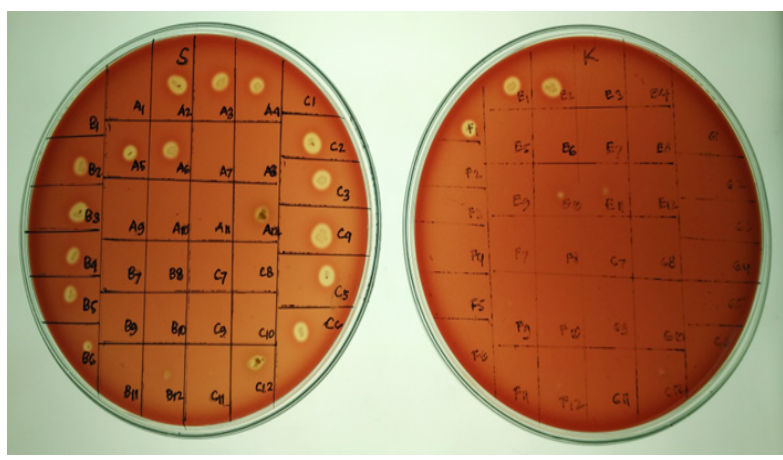

A
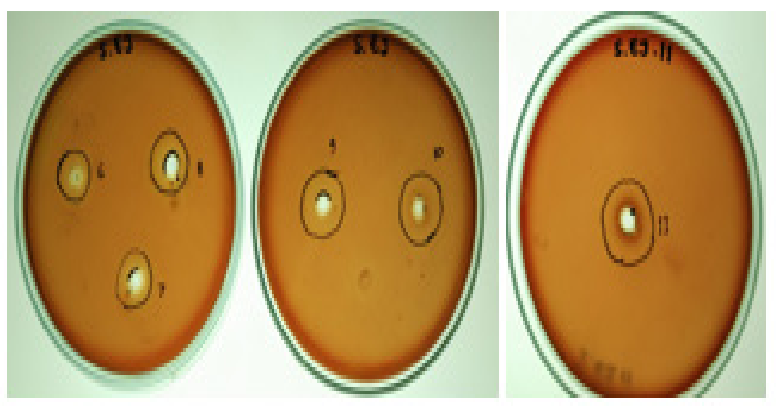

B
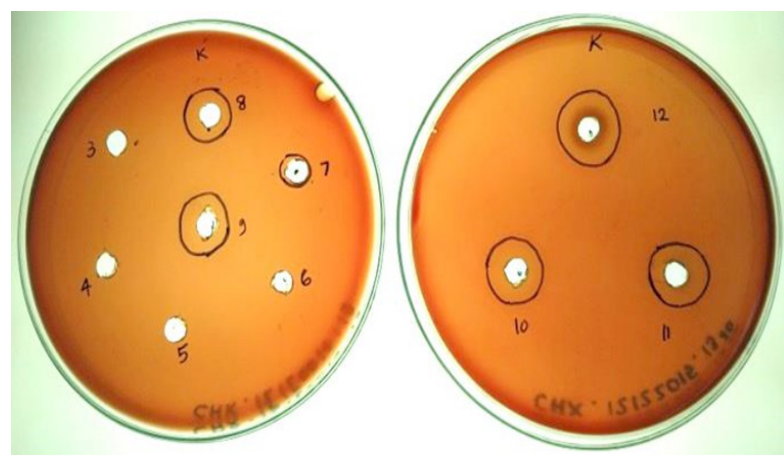

C

Picture 5. A. Observation of blood agar cultured to determine $M B C ; B$. linhibition zone of extract of Zingiber officinale; $\mathrm{C}$. linhibition zone of $\mathrm{Ch}$ lorhexidine is densitive to the extract of Zingiber officinale Roscoe and the study continues.

The MIC of the extract of Zingiber officinale Roscoe could not be clearly observed visually. The $M B C$ for Zingiber officinale Roscoe extract was $15.625 \mathrm{mg} / \mathrm{mL}$, while clorhexidine was $1.25 \mathrm{mg} /$ $\mathrm{mL}$.

\section{DISCUSSION}

In this study, the MIC could not be determined by visual inspection as all wells in the microplate was muddy except negative control. Therefore, the MIC was eliminated from the study and to evaluate antibacterial activity, MBC were used as the indicator.

MBC for extract of Zingiber officinale Roscoe was $15.625 \mathrm{mg} / \mathrm{mL}$ which is equivalent to $1.56 \%$. This shows that extract of Zingiber officinale Roscoe starts to work as a bactericide to $E$. faecalis at the concentration $15.625 \mathrm{mg} / \mathrm{mL}$, whereas the MBC for clorhexidine as positive control was 1.25 $\mathrm{mg} / \mathrm{mL}$ which is equivalent to $0.125 \%$. The highest mean of diameter of inhibition zone of extract of Zingiber officinale Roscoe

Extract of Zingiber officinale Roscoe has an antimicrobial activity against $E$. faecalis. This may be caused of the presence of gingerol and shogaol as active ingredient within ginger, as mentioned in many studies indicated that the antimicrobial potency of ginger mainly caused by the presence of oxygenated mono- and sesquiterpenes, phenolic compounds (shogaol, gingerol), which are lipidsoluble phenol compounds primarily isolated from the root of ginger. Gingerol and shogaol was bactericidal and bacteriostatic components

Table 1. Means of diameters inhibition zone of extract Etanol Zingiber officinale Roscoe which concentration which no growth bactery

\begin{tabular}{ccccccc}
\hline Concentration $(\mathrm{mg} / \mathrm{mL})$ & 15,625 & 31.25 & 62.5 & 125 & 250 & 500 \\
\hline Mean Inhibition Zone $(\mathrm{mm})$ & 13.87 & 15,23 & 16,20 & 18,22 & 18,35 & 20,48 \\
\hline
\end{tabular}

Table 2. Result of determine MBC extract Etanol Zingiber officinale Roscoe to E. faecalis

\begin{tabular}{ccccccccccccc}
\hline & $\mathrm{KM}$ & $\mathrm{KB}$ & 0.977 & 1.953 & 3.906 & 7.813 & 15.625 & 31.25 & $6 ., 5$ & 125 & 250 & 500 \\
\hline $\mathrm{I}$ & - & + & + & + & + & + & - & - & - & - & - & - \\
$\mathrm{II}$ & - & + & + & + & + & + & - & - & - & - & - & - \\
$\mathrm{III}$ & - & + & + & + & + & + & - & - & - & - & - & - \\
\hline
\end{tabular}


could break the phospholipid membrane became permeable due to released main components of cell and inhibit membrane function (electron transport, nutrient supply, synthetic of nucleat acid and enzym activity). Some of that components had invasive target due to bacterial pathogenity.

Mean of diameters of inhibition zone at MBC was similar. Analysis of Anova had confirmed that $M B C$ of the extract of Zingiber officinale Roscoe and clorhexidine had significant differences. It showed that result of $M B C$ was valid. It explained that to begin killed $E$. Faecalis, extract of Zingiber officinale Roscoe need ten times higher concentration than clorhexidine. It showed that to achieve antibacterial activity of clorhexidine as gold standard of root canal irrigant, a concentration of extract of $15.625 \mathrm{mg} / \mathrm{mL}$ Zingiber officinale Roscoe is needed.

\section{CONCLUSSION}

Extract of Zingiber officinale Roscoe had antibacterial activity againts $E$. Faecalis possibly to its phenolic compound which soluble in lipid and has the ability to rupture the phospholipid membrane of the bacteria. To achieve an equal bactericidal activity as chlorhexidine, a concentration of $15.625 \mathrm{mg} / \mathrm{ml}$ is needed.

\section{ACKNOWLEDGMENTS}

The authors deny any conflicts of interest related to this study.

\section{REFERENCES}

1. Sjögren U, Figdor D, Persson S, Sundqvist G. Influence of infection at the time of root filling on the outcome of endodontic treatment of teeth with apical periodontitis. Intern Endod J 1997; 30: 297-306.

2. Hasselgren G, Olsson B, Cvek M. Effects of calcium hydroxide and sodium hypochlorite on the dissolution of necrotic porcine muscle tissue. J Endod 1988; 14: 125-7.

3. Kovac J, Kovac D. Effect of irrigating solutions in endodontic therapy. Bratisl Lek Listy. 2011; 7: 410-415.

4. Pujar M, Makandar S. Herbal usage in endodontics- A review. Intern J Contemp Dent
2011; 2: 34-37.

5. Demin G, Yingying, Z (2010) Comparative antibacterial activities of crude polysaccharides and flavonoids from Zingiber officinale and their extraction. American Journal of Tropical Medicine 5: 235-238.

6. Sasidharan I, Nirmala Menon A (2010) Comparative Chemical Composition and Antimicrobial Activity Fresh \& Dry Ginger Oils (Zigiber Officinale Roscoe).International Journal of Current Pharmaceutical Research 2: $40-43$.

7. Sebiomo A, Awofodu AD, Awosanya AO, Awotona FE, Ajayi AJ (2011) Comparative studies of antibacterial effect of some antibiotics and ginger (Zingiber officinale) on two pathogenic bacteria. Journal of Microbiology and Antimicrobials 3: 18-22.

8. Lee YB, Kim YS, Ahmore CR (1986) Antioxidant property in ginger rhizoma and its application to mate products. Journal of Food Science 51: 20-23.

9. Penna SC, Medeiros MV, Aimbire FS, Faria-Neto HC, Sertié JA, et al. (2003) Anti-inflammatory effect of the hydralcoholic extract of Zingiber officinale rhizomes on rat paws and skin edema. Phytomedicine 10: 381-385.

10. Kadnur SV, Goyal RK (2005) Beneficial effects of Zingiber officinale Roscoe on fructose induced hyperlipidemia and hyperinsulinemia in rats. Indian J Exp Biol 43: 1161-1164.

11. Islam MS, Choi H (2008) Comparative effects of dietary ginger (Zingiber officinale) and garlic (Allium sativum) investigated in a type 2 diabetes model of rats. J Med Food 11: 152159.

12. Kim JS, Lee SI, Park HW, Yang JH, Shin TY, et al. (2008) Cytotoxic components from the dried rhizomes of Zingiber officinale Roscoe. Arch Pharm Res 31: 415-418.

13. Isa $Y$, Miyakawa $Y$, Yanagisawa $M$, Goto $T$, Kang MS, et al. (2008) 6-Shogaol and 6-gingerol, the pungent of ginger, inhibit TNF-a mediated down regulation of adiponectin expression via different mechanisms in 3T3-L1 adipocytes. Biochem and Biophys ReS Commun 373: 429434.

14. Wang W, Li CY, Wen XD, Li P, Qi LW (2009) Simultaneous determination of 6-gingerol, 8-gingerol, 10-gingerol and 6-shogaol in 
rat plasma by liquid chromatographymass spectrometry: Application to pharmacokinetics. J Chromatogr B Analyt Technol Biomed Life Sci B 877: 671-679.

15. Shim S, Kim S, Choi DS, Kwon YB, Kwon J (2011) Anti-inflammatory effects of [6]-shogaol: Potential roles of HDAC inhibition and HSP70 induction. Food Chem Toxicol 49: 2734-2740.

16. Park M, Bae J, Lee DS. Antibacterial Activity of [10] Gingerol and [12]-Gingerol isolated from Ginger Rhizome against Periodontal Bacteria. Phytother Res 2008; 22: 1446-1449.

17. Sebiomo A, Awofodu AD, Awosanya AO, Awotona FE, Ajayi AJ. Comparative studies of antibacterial effect of some antibiotics and ginger (Zingiber officinale) on two pathogenic bacteria. J Microbiol Antimicrob. 2011; 3: 18-
22.

18. Atai Z, Atapour M, Mohseni M. Inhibitory Effect of Ginger Extract on Candida albicans. Am J Appl Sci. 2009; 6: 1067-1069.

19. Gulve MN, Gulve ND. Comparison of Antimicrobial Efficacy of Ginger Extract and 2\% Sodium Hypochlorite against Enterococcus faecalis using agar diffusion method. J Ind Dent Assoc 2010; 4: 347-349.

20. Lin S, Zuckerman O, Wiess El, Mazor Y, Fuss Z. Antibacterial efficacy of a new Chlorohexidine slow release device to disinfect tubules. J Endod 2003; 29: 416-418.

21. Jeansonne MJ, White RR. A comparison of $2 \%$ Chlorohexidine glugonate and $5.25 \%$ sodium hypochlorite as antimicrobial endodontic irrigant. J Endod 1994; 20: 276-278. 